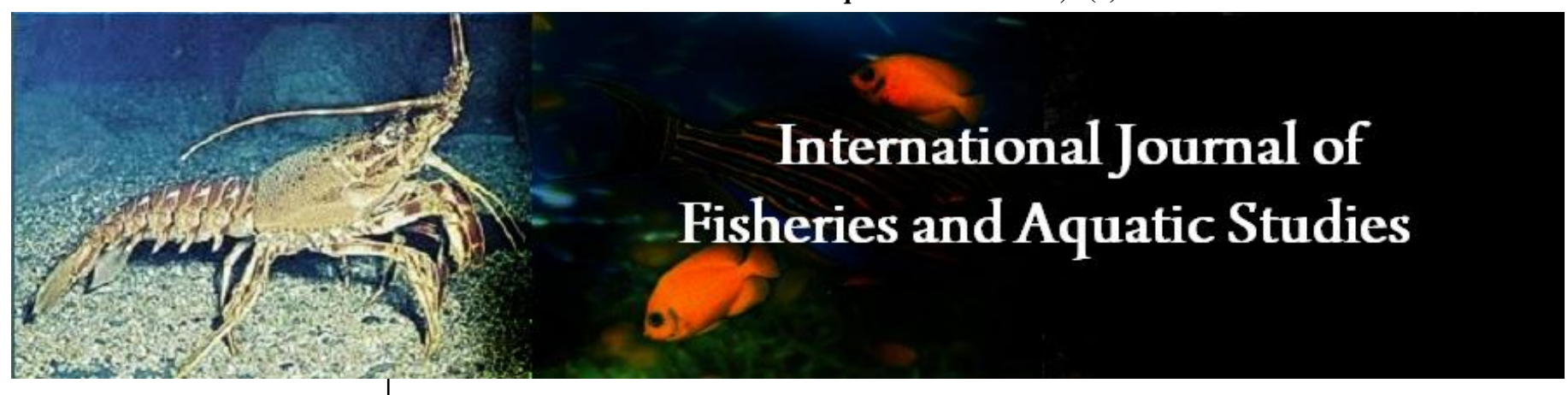

E-ISSN: 2347-5129

P-ISSN: 2394-0506

(ICV-Poland) Impact Value: 5.62

(GIF) Impact Factor: 0.549

IJFAS 2021; 9(4): 234-238

(C) 2021 IJFAS

www.fisheriesjournal.com

Received: 19-05-2021

Accepted: 21-06-2021

Ndome CB

Zoology and Environmental

Biology, University of Calabar,

Calabar, Nigeria

Olaleye IG

Institute of Oceanography,

University of Calabar, Calabar,

Nigeria

Ubangha II

Zoology and Environmental

Biology, University of Calabar,

Calabar, Nigeria
Corresponding Author:

Olaleye I.G

Institute of Oceanography,

University of Calabar, Calabar,

Nigeria

\section{The ichthyofauna of the upstream and downstream reaches of the KWA fall, Oban, Akamkpa L.G.A. cross River state, Nigeria}

\author{
Ndome CB, Olaleye IG and Ubangha II
}

DOI: https://doi.org/10.22271/fish.2021.v9.i4c.2541

\begin{abstract}
A study of the fish status of Kwa falls water body was carried out for three months (August-October) and a total of 562 fish representing 12 species belonging to 11 genera from 10 families and 6 orders were sampled. The family Clariidae was represented by Clarias gariepinus, Cichlidae by 2 species: Oreochromis niloticus and Tilapia zillii, Mockokidae by Synodontis omias and Schilbeidae by Schilbe uranoscopus. Claroteidae by 2 species: Chrysichthys nigrodigitatus and Chrysichthys longipinnis, Mugilidae by Mugil falcipinnis. The rest includes Paralichthyidae (Citharichthys stamflii), Characinidae (Sarcodaces odoe), Eleotridae (Eleotris vittata) and the Cyprinidae (Barilius niloticus). Siluriformes and Perciformes were the most abundant orders accounting for $72.2 \%$ and $14.8 \%$ of the total landings respectively while the species Chrysichthys nigrodigitatus (313), C. longipinnis (72) and Oreochromis niloticus (56) dominated the overall catch constituting $87.5 \%$. Monthly differentiation in the diversity indices revealed higher values for the month of October than the month of August and September. The Shannon-wiener index $\left(H^{\prime}\right)$ obtained were within the range of 0.75 to 1.74 and showed significant difference between reaches, with downstream reaches having higher diversity throughout the sampling period. Equitability values (E) were generally low in all the reaches sampled. The spatial and seasonal differences were significant at $\mathrm{p}<0.05$.
\end{abstract}

Keywords: ichthyofauna, Kwa fall, fauna, sampling site and occasion

\section{Introduction}

Fish fauna of watershed are a valuable resource from ecological and economic viewpoints; for natural management and conservation of the fish resource, a critical survey of the fish faunal composition is important ${ }^{[1]}$. Fish fauna comprises over $40 \%$ of the earth's vertebrate species and are a vital link between primary producers and various levels of consumers in the food chains. Among the aquatic organisms, fish enjoys the prime position and is of considerable importance in providing proteins, vitamins, minerals, fats (Omega-3) and various other nutrients required for nourishment and growth of $\operatorname{man}^{2}$. Fishes, not only supplement to nutritious diet, but are also a source of income and employment opportunities for the skilled and unskilled workers ${ }^{[2]}$. A waterfall is a place where a stream or river falls from a high place example over a cliff or rock ${ }^{[3]}$. It is caused by gravity taking its effect on water and pulls it down a cliff ${ }^{[4]}$ which is known to form a rich biome for indigenous and exotic species which are swept upstream and over the waterfalls to settle downstream in a more quiescent environment. The range of distribution of fish species from the source (upstream) to the discharge point (downstream) is determined by the ecological requirements of each fish species ${ }^{[5]}$. Kwa falls is a thrilling and spectacular waterfall located in a narrow, steep gorge on the headwaters of the Great Kwa River, in the Oban region of the Cross River National Park [6]. Waterfalls and their fisheries had received very little attention from researchers all over the world. In Africa, the reason being that, waterfalls were named after deities and were used as places of traditional and ancestral worships. In other places, the intensity of waterfalls and pressure generated from them due to gravity has given the impression of a lifeless zone ${ }^{[4]}$. Knowledge of waterfalls systems in Africa are therefore limited to hydrology and geological features ${ }^{[7]}$, natural monuments for revenue generation because of their ecotourism potentials especially sport fishing, and as source for drinking, irrigation and other domestic purposes ${ }^{[8]}$. 
For sustainable exploitation of the fisheries resources of Kwa falls, knowledge of status of the Ichthyofauna of the waterfalls is important in the management and conservation of the resources. This research was to carried out with the aim of investigating the Ichthyofauna of the upstream and downstream reaches of the waterfall, determining the relative abundance and species diversity of the various fish groups and examine the distribution of the fish species in the different section of the waterfalls.

\section{Materials and Methods}

Kwa falls is located in a narrow, steep gorge on the headwaters of the Great Kwa River, in the Oban region of the Cross River National Park, between latitude $5^{\circ} 25^{\prime} 0^{\prime}$ ' $\mathrm{N} / 5.41667^{\circ} \mathrm{N}$, and longitude $8^{\circ} 35^{\prime} 0^{\prime}$ ' $\mathrm{E} / 8.58333^{\circ} \mathrm{E}{ }^{[9]}$. The climate of the study area is tropical-humid with wet and dry seasons, with temperatures ranging between $15^{\circ} \mathrm{C}-30^{\circ} \mathrm{C}$. The rainy season lasts from March to November, with annual rainfall of over $3,500 \mathrm{~mm}$. Relative humidity is high, between $80 \%$ and $100 \%{ }^{[7]}$.

\section{Collection of samples}

Samples were obtained from fishermen who uses a variety of fishing gear (gill net, seine net, cast net, local traps, hook and line) to catch them. Representative fish samples from the two sampling site (upstream and downstream) were preserved in $4 \%$ formalin in a labeled container (according to the collection site, date and time) and were transported to the Department of Zoology and Environmental Biology laboratory, in University of Calabar, for identification.

\section{Identification/classification of fish samples}

All preserved samples were removed from the formalin, rinsed in clean water and placed slanting with the mouth down to drain out excess fluid for about 10 minutes prior to identification. The fishes were identified using appropriate identification key guides ${ }^{[10-12]}$. After the identification of fish species, numerical data obtained from the field for each fish species were recorded accordingly to determine the total number of samples per sampling site and occasion. Photographs of the identified samples were taken using a camera.

\section{Determination of species composition, abundance and biodiversity indices}

Species composition and abundance per sampling site and occasion were determined in percentage. Margalef's Index $(d)$, Shannon-Weiner Index (H') and Simpson's Index $(D)$ were used to determine the species diversity and richness.

\section{Statistical analysis}

Analysis of variance (ANOVA) was used to see if there were any significant differences in the data at the two sampling stations.

\section{Results}

During the study a total of 562 fish representing six (6) orders, ten (10) families, eleven (11) genera and twelve 12 species were sampled between the month of August and October 2017. The family Clariidae was represented by Clarias gariepinus, the Cichlidae was represented by 2 species; Oreochromis niloticus and Tilapia zillii, the Mackokidae was represented by Synodontis omias and the Schilbeidae was represented by Schilbe uranoscopus. The Claroteidae was represented by 2 species; Chrysichthys nigrodigitatus and Chrysichthys longipinnis. The Mugilidae was represented by Mugil falcipinnis. The Paralichthyidae was represented by Citharichthys stamflii. The Characinidae was represented by Sarcodaces odoe. The Eleotridae was represented by Eleotris vittata and the Cyprinidae was represented by Barilius niloticus (Table 1).

Table 1: Checklist of species sampled during the study

\begin{tabular}{|c|c|c|c|c|}
\hline $\mathbf{S} / \mathbf{N}$ & Species & Common Name & Family & Order \\
\hline 1 & Schilbe uranoscopus & Butter Catfish & Schilbeidae & \multirow{5}{*}{ Siluriformes } \\
\hline 2 & Clarias gariepinus & Catfish & Clariidae & \\
\hline 3 & Chrysichthys nigrodigitatus & Silver Catfish & \multirow{2}{*}{ Claroteidae } & \\
\hline 4 & Chrysichthys longipinnis & Big eye Catfish & & \\
\hline 5 & Synodontis omias & Squeakers & Mochokidae & \\
\hline 6 & Mugil falcipinnis & Mullet & Mugilidae & Mugiliformes \\
\hline 7 & Citharichthys stamflii & Smooth Flounder & Paralichthyidae & Pleuronectiformes \\
\hline 8 & Sarcodaces odoe & African Pike & Characinidae & Characiformes \\
\hline 9 & Oreochromis niloticus & Nile tilapia & \multirow{2}{*}{ Cichlidae } & \multirow{3}{*}{ Perciformes } \\
\hline 10 & Tilapia zilli & Red belly tilapia & & \\
\hline 11 & Eleotris vittata & Sleepers & Eleotridae & \\
\hline 12 & Barilius niloticus & Nile minnow & Cyprinidae & Cypriniformes \\
\hline
\end{tabular}

Species composition per sampling site and sampling occasion

The total number of species sampled at each of the sampling site is shown in Fig. 1. The number of taxa at upstream and downstream reaches were 9 and 12 respectively. Citharichthys stamflii, Mugil falcipinnis and Eleotris vittata were recorded only at the downstream section and absent at the upstream section. In each of the sampling occasion, the total number of species sampled is shown in Fig. 2. September and October recorded the highest number of species. Chrysichthys nigrodigitatus, Chrysichthys longipinnis, Oreochromis niloticus were the only fish species recorded in August. Citharichthys stamflii was only recorded in September and absent in both August and October, while Eleotris vittata was recorded only in October and absent in August and September. 


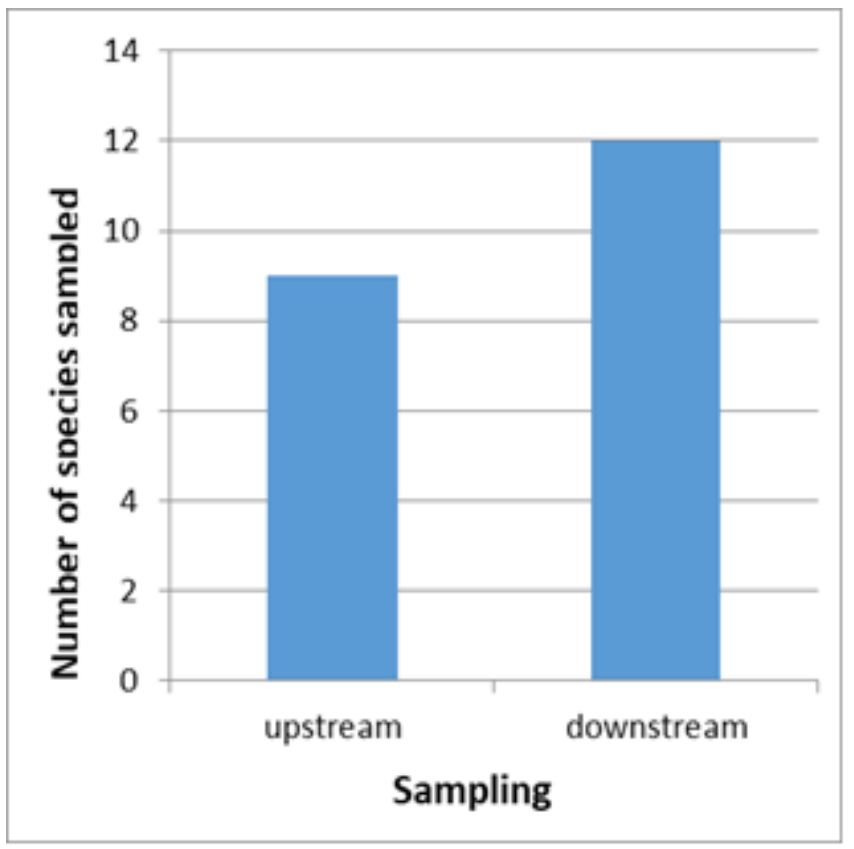

Fig 1: Species composition per sampling site

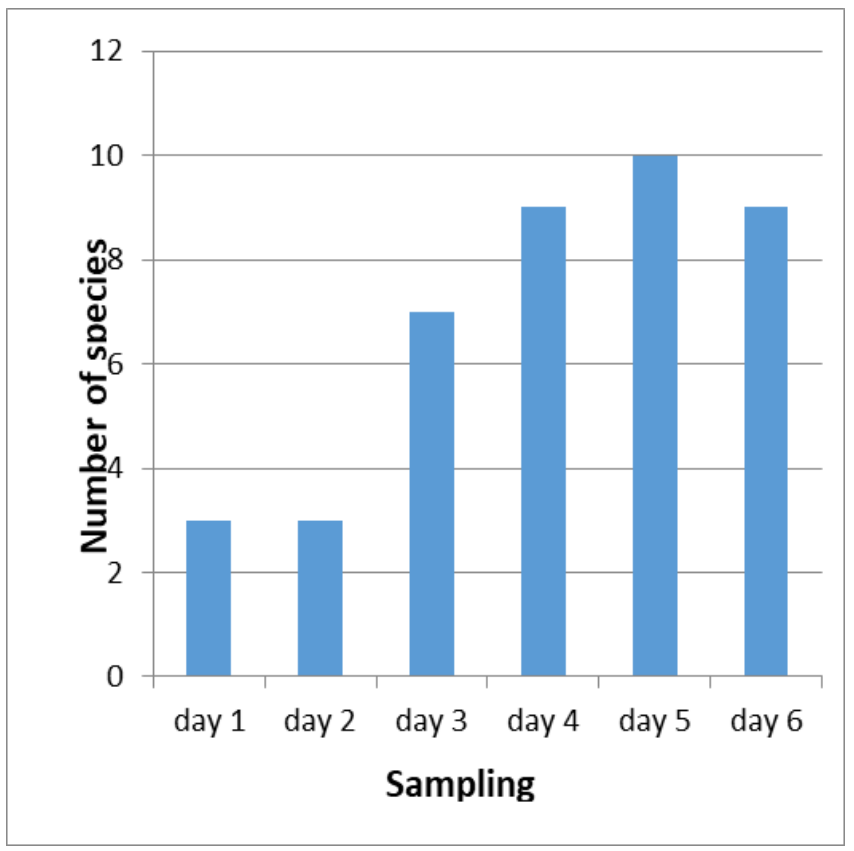

Fig 2: Species composition per sampling occasion

\section{Percentage composition of species per sampling site and occasion}

The percentage composition of species at the sampling sites and occasion is shown in Table 2. The downstream site had the highest percentage composition of species (100\%) of all the total species recorded, while upstream site had the lowest percentage composition of species (75\%). During the sampling occasion, day 5 recorded the highest percentage $(83.3 \%)$ of the total species recorded while day $1(25 \%)$ and day $2(25 \%)$ recorded the least percentage composition.
Table 2: \% composition of species at sampling site and sampling occasion

\begin{tabular}{|c|c|c|}
\hline Sampling site/occasion & Number of species & \% composition \\
\hline Upstream & 9 & 75 \\
\hline Downstream & 12 & 100 \\
\hline Day 1 & 3 & 25 \\
\hline Day 2 & 3 & 25 \\
\hline Day 3 & 7 & 58.3 \\
\hline Day 4 & 9 & 75 \\
\hline Day 5 & 10 & 83.3 \\
\hline Day 6 & 9 & 75 \\
\hline
\end{tabular}

\section{Species abundance per sampling site}

Of the 562 total catch recorded during this study, Chrysichthys nigrodigitatus (313), C. longipinnis (72) and Oreochromis niloticus (56) dominated the overall catch. The numbers of individuals present at upstream and downstream reaches were 265 and 297 respectively and Chrysichthys nigrodigitatus dominated both in the upstream (133) and downstream (180) reaches. Synodontis omias (5) was the least abundant upstream while Citharichthys stamflii (2) and Barilius niloticus (2) were the least abundant downstream. Citharichthys stamflii, Mugil falcipinnis and Eleotris vittata were absent at the upstream and were recorded only at the downstream sections of the Kwa falls as shown in Fig. 3.

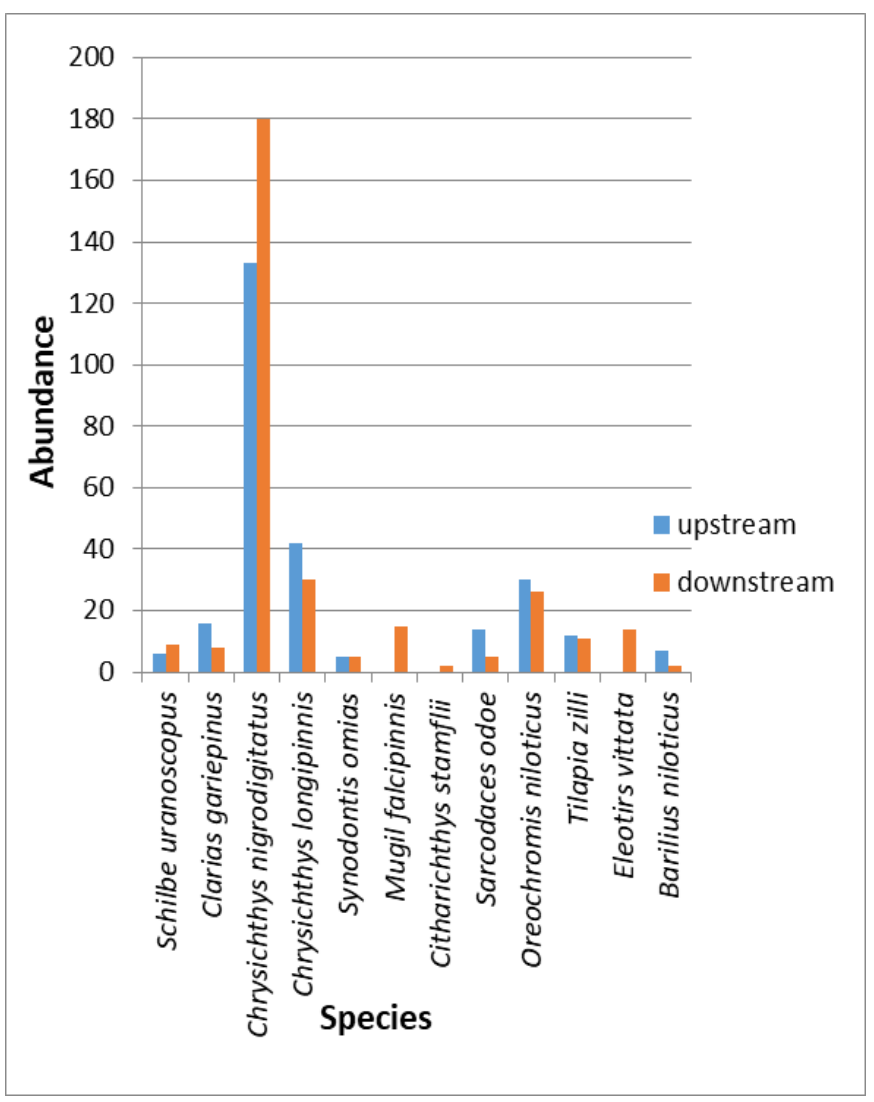

Fig 3: Species abundance per sampling site 


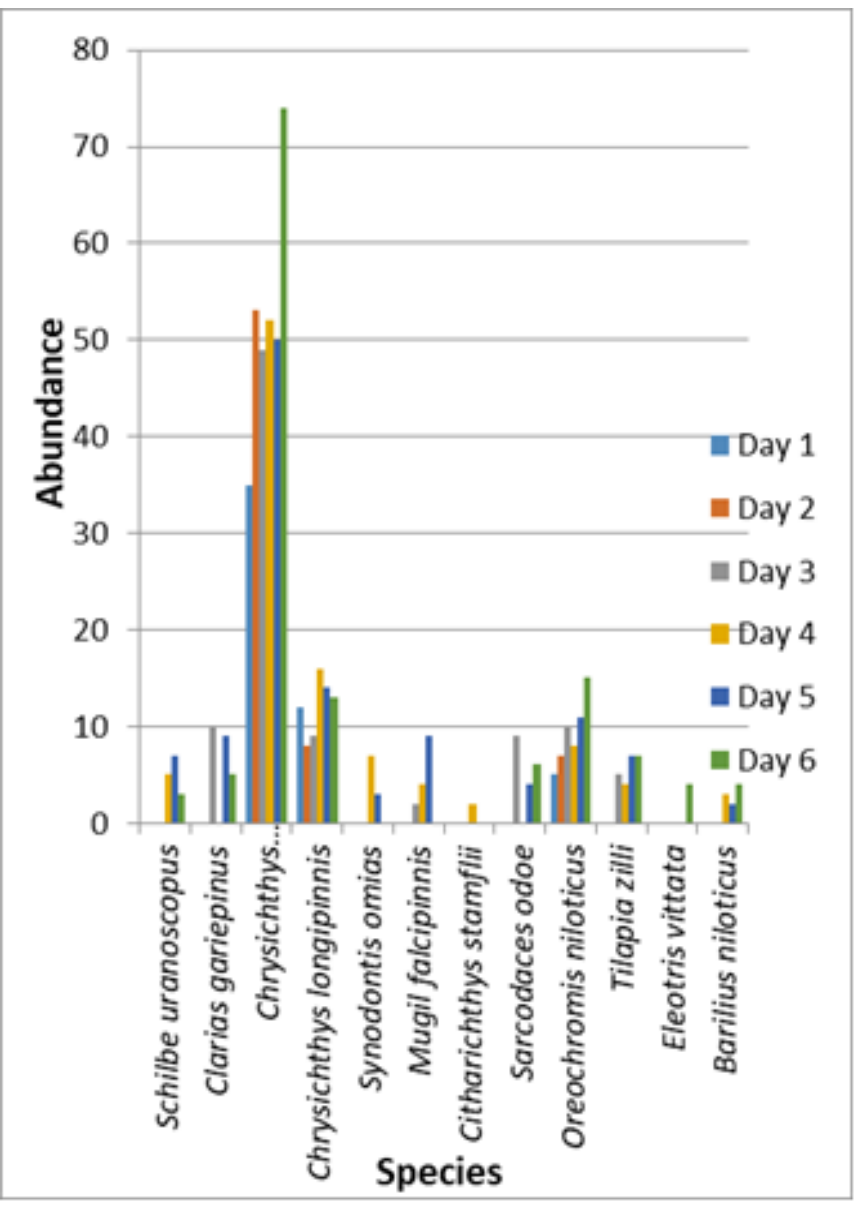

Fig 4: Species abundance per sampling occasion

\section{Species abundance per sampling occasion}

In terms of monthly species abundance, September and October recorded the highest values while August recorded the least values, 195, 247 and 120 respectively with Chrysichthys nigrodigitatus dominating the total number of catch in August (88), September (101) as well as October (124), while Citharichthys stamflii (2) and Eleotris vittata (4) were the least abundant in September and October respectively. Chrysichthys nigrodigitatus, Chrysichthys longipinnis, Oreochromis niloticus were the only fish species recorded in August. (Fig. 4)

\section{Percentage abundance of species sampled per station and occasion}

The percentage abundance of species sampled per station is shown in table 3. Chrysichthys nigrodigitatus had the highest percentage abundance both in the upstream (50.2\%) and downstream $(60.6 \%)$ reaches. Synodontis omias $(1.9 \%)$ had the least percentage abundance upstream while Citharichthys stamflii $(0.7 \%)$ and Barilius niloticus $(0.7 \%)$ had the least abundance downstream. Also, the percentage abundance of species sampled per occasion is shown in table 4. Day 1 recorded the least percentage abundance of species sampled while day 6 recorded the highest percentage abundance of species sampled.

Table 3: Percentage abundance of species sampled per station

\begin{tabular}{|c|c|c|}
\hline \multirow{2}{*}{ Species } & Upstream & Downstream \\
\cline { 2 - 3 } & $\mathbf{\%}$ & $\mathbf{\%}$ \\
\hline Schilbe uranoscopus & 2.3 & 3 \\
\hline Clarias gariepinus & 6 & 2.7 \\
\hline Chrysichthys nigrodigitatus & 50.2 & 60.6 \\
\hline Chrysichthys longipinnis & 15.9 & 10.1 \\
\hline Synodontis omias & 1.9 & 1.7 \\
\hline Mugil falcipinnis & - & 5.0 \\
\hline Citharichthys stamflii & - & 0.7 \\
\hline Sarcodaces odoe & 5.3 & 1.7 \\
\hline Oreochromis niloticus & 11.3 & 8.8 \\
\hline Tilapia zilli & 4.5 & 3.7 \\
\hline Eleotris vittata & - & 1.3 \\
\hline Barilius niloticus & 2.6 & 0.7 \\
\hline & 100 & 100 \\
\hline
\end{tabular}

Table 4: Percentage abundance of species sampled per occasion

\begin{tabular}{|c|c|c|}
\hline Sampling occasion & No of individuals & $\%$ \\
\hline Day 1 & 52 & 9.3 \\
\hline Day 2 & 68 & 12.1 \\
\hline Day 3 & 94 & 16.7 \\
\hline Day 4 & 101 & 18.0 \\
\hline Day 5 & 116 & 20.6 \\
\hline Day 6 & 131 & 23.3 \\
\hline Total & 562 & 100 \\
\hline
\end{tabular}

\section{Species Richness and Diversity Indices}

Monthly species richness and diversity indices estimated include Margalef's Index $(d)$; August (0.418), September (1.896) and October (1.815), Shannon-Weiner Index (H'); August (0.756), September (1.699) and October (1.741) and Simpson's index $(D)$; August (0.572), September (0.297) and October (0.284). Evenness index (E) was highest in October (1.59) and least in August (0.69). In the two stations, Margalef's Index $(d)$ shows higher richness in downstream section (1.932) than the upstream section (1.434) while Shannon-Weiner Index (H') shows higher diversity in the upstream section (1.606) than the downstream (1.555) and Simpson's diversity index $(D)$ showed higher values in downstream than the upstream section (0.366) and (0.297) respectively. Species Evenness (E) was higher in the upstream section than the downstream section, (0.73) and (0.63) respectively.

\section{Discussion}

The 6 orders consisting of 11 families, 10 genera and 12 species observed during this study, within the period of 3 months, shows that Kwa falls is rich in ichthyofauna and as a small riverine ecosystem, it compares favorably with the Agbokim waterfall which has 9 fish families consisting of 22 species ${ }^{13}$. In terms of species richness, the Claroteids and Cichlids were more dominant, agreeing with their high preponderance reported from other Nigerian Rivers. Four families of catfish (Schilbeidae, Clariidae, Claroteidae and Mackokidae) made up of 4 genera (Chrysichthys, Synodontis, Clarias and Schilbe) were encountered of which Chrysichthys nigrodigitatus was the dominant species which agrees with the findings on the fish fauna of Agbokum waterfall ${ }^{[13]}$. 
However, the dominance of Chrysichthys and the low population of species like Sarcodaces odoe and Clarias gariepinus in this study may be due to the fact that in fisheries, aggressive and competitively dominant fish are often the first to be over fished and are often in the habit of preventing subordinate fishes from taking baits ${ }^{[14]}$.

Monthly differentiation in the diversity indices in this study revealed higher values for the month of October than the month of August and September. The Shannon-wiener index $\left(H^{\prime}\right)$ obtained were within the range of 0.75 to 1.74 and showed significant difference between reaches, with downstream reaches having higher diversity throughout the sampling period. Although, Lawson \& Olusanya ${ }^{[15]}$ reported values of $H$ ' ranging from 1.869 to 2.015 in three tributaries of River Ore which are higher than those reported in this study. The difference can be attributed to disparity in ecological zones, hence the values for H' obtained for both monthly and by station in this study indicates a good spread of species diversity in Kwa falls. Also, the species richness index $(d)$ of Kwa falls is lower than those reported from some other related work. This may be attributable to the difference in number of species encountered. Nevertheless, Equitability values (E) were generally low in all the reaches sampled indicating high dominance by a few species (E.g. Chrysichthys nigrodigitatus, C. longipinnis and Oreochromis niloticus) in the overall catch and relatively high ShanonWienner diversity indices for the two sampling stations.

\section{Conclusion}

A total of 12 species belonging to 9 families were recorded in Kwa falls. The most numerically abundant fish families in descending order are the Claroteidae > Characinidae > Clariidae and the > Cichlidae. Although, the results in this study revealed that most families were represented by only single species while others were represented by two species, their relative abundance significantly varied between species and families but did not significantly vary between stations. The monthly variation of the catch during the study revealed that there were comparatively higher catches of fish in October than in August probably due to reduced water volume which concentrated the fish for easier catchability. Likewise, downstream reaches recorded highest diversity throughout the period of sampling with higher values for the October than the month of August, hence, months typical of little rainfall like the downstream section of the Kwa falls is critical in monitoring fish stock of the water falls.

\section{References}

1. King RP. Biodiversity of freshwater fishes of the Cross River in the rainforest belt of Cameroon - Nigeria. Journal of Aquatic Science 1992, 184-197.

2. Sharma S, Sharma P, Siddique A, Belsare DK. Fish species diversity of Sirpur lake, Indore (M.P.), India. Him. J Env. Zool 2007;18(2):349-352

3. Cano R. World waterfalls guide. Retrieved from http:/www.home.att.net// j.i. cano/waterfalls/index.htm on the 09/22/05 2000 .

4. Chernicoff S, Fox H, Venkatakrishnan R. Essentials of geology. Worth Publishers, New York 1997, 217p.

5. Ferreirta FC, Petrere Jr M. The fish zonation of the Itanhaem river basin in the Atlantic Forest of southeast Brazil. Hydrobiologia 2009;363:11-34.

6. Aga T, Atane G, Baba J. The Geology and Geotourism Potential of the Mayes Water Fall, North Central Nigeria.
Global Advanced Research Journal of Geology and Mining Research 2013;1(1):007-013.

7. Fischer G, Harris M. Waterfalls of Ontario. "Waterfallogy" 2003,101. Retrieved from http.//www.startica/user/mharris/waterfallogy.ht $\mathrm{m} /$ on the $17 / 01 / 06$.

8. Ayodele IA. An ecological basis for the management of Old Oyo National Park. Ph. D. Thesis, University of Ibadan 1988,220p.

9. CRNP. Cross River National Park. Important bird areas factsheet, Oban Division 2010. Retrieved from http://www.birdlifeinternational.org/ Cross River National Park on the 09/06/17

10. Idodo-Umeh G. Freshwater fishes of Nigeria (Taxonomy, Ecological notes, Diets and Utilization). $1^{\text {st }}$ Edition Published by Idod 2003.

11. Adesulu EA, Sydenham DH. The freshwater fishes and fisheries of Nigeria. Macmillan Nigeria Publishers Limited, Yaba, Lagos 2007, 397p

12. Olaosebikan BD, Raji A. Field guide to Nigeria freshwater fishes (Revised edition). University of Ilorin Press, Nigeria 2013,1-89

13. Ikpi G, Offem B. Fishery and the tourism potential of Agbokim waterfalls, Nigeria. Journal of Water Resource and Protection 2012;4:733-745.

14. McClanahan TR, Graham NAJ, Wilson SK, Letourneur Y, Fisher R. Effects of fisheries] closure size, age, and history of compliance on coral reef fish communities in the western Indian Ocean. Mar Ecol Prog Ser 2009;396:99-109.

15. Lawson OE, Olusanya OM. Fish diversity in three tributaries of River Ore, South West Nigeria.] World Journal of Fish and marine sciences 2010;2(6):524-531. 